\title{
Broadcasting Applications of Local Wisdom Character on Coastal Environment in Communication Media
}

\author{
Riris Tiani $^{1 *}$ and M.Suryadi ${ }^{1}$ \\ ${ }^{1}$ Lecturer in Faculty of Humanities, Diponegoro University, Semarang-Indonesia
}

\begin{abstract}
This study aims to determine the effect of television shows on people's verbal behavior. Natnography used as a research method, to find out the types of television programs that are seen by many people of all ages. Cultural studies methods also used to determine the negative impact of television broadcast content. How the influence of television shows on the style of public communication in forming the character of millennial society. In-depth interview techniques with KPID and representatives of national television stations. Based on research in the field, television shows are present for 24 hours in the family room. Culture that accepted in society that television has not become a spectacle but has become a demand. Broadcasting institutions control the formation of mental, social, and cultural. The results of this study include many Impoliteness television shows. The reality in broadcasting shows that FTV content, talk shows, and advertisements have the most verbal abuse (VA) frequencies. Form (VA) is dominated by abuse, swear, invective, and (nonVA). $60 \%$ of the broadcasting composition in the media must be educative with local wisdom, 20\% national or international public broadcasting, 20\% broadcast advertising content. Forms of impertinence are influenced by frequency, television cognition, and broadcast regulation.
\end{abstract}

Keywords: broadcasting; impoliteness; media.

\section{Introduction}

Television has a very important role in people's lives. Almost everyone uses television media to get information and sources of entertainment. The development of technology certainly also plays an important role in promoting the development of increasingly fast and massive information. Explosive changes in the global era have an effect on the level of consumer information in creating a mass media space to develop. The emergence of the internet brings major changes at the community and individual levels [1]. The mass media represents the totality of mass information including radio, television, the press, the internet, and others. Mass media has the main function of conveying information. Communities are increasingly computerized and significantly experience changes in behaving individually. Education in the field of media communication must be given to students and teachers through writing training and teachers must provide media communication skills to the giver or recipient of information [1].

This condition must be realized by policy holders in broadcasting institutions, which become controllers in the formation of mental, social, cultural communities. The mental, social and cultural formation of the community is influenced by the surrounding environment. It is no exception television shows that every day for 24 hours present "without permission" in the private spaces of the family. Television shows are one of the media that contain such impoliteness. Impoliteness and modern communication: offers three case studies of impoliteness in modern communication; it is an oral communication or virtual communication [2]. Impoliteness, in the virtual world, is reflected in the form of public communication, both parents to children and vice versa in formal or non-formal situations. This phenomenon in the realm of pragmatic studies is called Verbal Abuse (VA). VA has an impact on horizontal collisions in the society which today often occurs in both adolescents and students.

Verbal Abuse is a linguistic phenomenon as it has a negative impact on social harmonization in society. Horizontal collisions in coastal area communities often occur because of the characteristics of the people who tend to be weak, passive, and destructive. Communities in coastal areas such as Semarang, especially on the North coastline, are very far from polite civilization. Inevitably horizontal conflicts in the community often occur. One of the triggers is the adaptation of shows on television both verbal and nonverbal. Television shows have many positive and negative influences. It has just that the phenomenon occurs in coastal area communities in which the community is not ready to accept megapolitan culture through television shows. Therefore, coastal communities experience cultural shock which reflected in the impoliteness of verbal

\footnotetext{
${ }^{*}$ Corresponding author: tiani.riris@gmail.com
} 
abuse so that it gives an impact on the mental changes of coastal areas.

\section{Method}

This study uses the Cultural Studies method which was introduced by the Birmingham Center for Contemporary Cultural Studies (BCCCS) by Richart Hoggart in 1964. It is said that Cultural studies as a cultural approach through a critical perspective and use many scientific disciplines [3]. More placing culture in the theory of social production and reproduction, clarifying the variety of cultures can play a role in advancing the importance of social mastery or making people reject and struggle against such mastery. The approach used neutrography with the aim is to see the effect of electronic media impressions on the psychological community in the coastal environment. This study involved elementary school students, junior high school students, high school students, teachers, and parents of the students, including in-depth interviews with KPID and representatives of television station owners. The data is then reduced to see the percentage of impressions that have a negative impact on the environment of coastal communities. After being scrutinized and obtained statistical data, it was concluded that making the policy of television shows.

\section{Results and Discussions}

\subsection{The Role of Television Shows in making the society character}

According to Burton [4] who explained the process of ideology through broadcasting on television would affect the mental formation of the society. The mental formation of society is not just given at school. In line with the opinion of Florescu [1] that the responsibility of education and character building of people is not enough from family or school. The most significant of the character building is influenced by the environment of media communication. The mental formation of the individuals must be integrated with the social environment. The social environment increases along with the development of educational media and communication media. The balance of the social environment and the media communication environment is much important in making the local wisdom character building of coastal communities.

The content of virtual communication on Indonesian television shows is still widely criticized as it is not reflecting the true national character. The shows are lack of education, less exploring local wisdom, and some prioritizing political interests. Those shows, of course, affect the audiences' mentality and behavior, so that many people use the verbal impoliteness abuse to interact among others.

The reality occurs in the television world is currently experiencing a shift in its function. The media not only provides the facts but also ideologies that reside in its content. The hidden messages of the shows are interesting to be studied for the real messages are not accidentally born but they are done with careful planning, construction, and distribution which reflect the ideology. The ideology of the shows on television shifts to follow such hegemony and circle of the political economy of the media. Similar research conducted by [5] is believed that repeated television shows will have an effect on real life though it is a form of entertainment. The influence of the shows on television can change the cognitive process, the affective process and the behavioral process, which possibly leads to desensitization. Jeanne's research (2003) aims to determine whether there is a relationship between real life and exposure to television media violence which is broadcast repeatedly. The result of her research is that exposure to violence on television media had low influence on the level of indifference. Whereas violent film shows have a stronger influence on the level of indifference. Playing video games intensely will develop the fantasy power of high fantasy games but it has a negative impact [5].

The reality of large collaboration cannot be denied. There is a strong relationship, state base power collaboration can be interpreted as a state power that currently covers the world of broadcasting and market base power, which is interpreted as the market power of capital owners who are very market oriented. The collaboration is interpreted as an effort to gain profit from the perspective of media political economy. Pattern construction applied in the practice of producing television shows experiences semiotic mixing and visual and audio-visual forms. Struat Hall [6] through publications related to encoding and decoding the televisual discourse revealed that media production is framed entirely by meanings and ideas, the practice of knowledge concerning the routine of production. Media production historically defined as technical expertise, professional ideology, institutional knowledge, definitions and assumptions, the assumption of audiences to further frame the composition of the program through this production structure. Then, television productions become the embryo of the television program. The structure of television production raises topics, agendas, events, and images of audiences from various sources. Changes in communication culture have resulted in increased interconnection in coastal communities. The power of homogenization of globalization is interrelated with changes in the way of communicating and produces an instant way of thinking of society [7].

The news production process is almost indistinguishable from the production of soap opera/FTV/film. Thus, the reality of being moved in $3 \mathrm{D}$ conditions into $2 \mathrm{D}$ on a glass screen is increasingly not the same as the real world. In fact, the communities who viewing television programs actually see the television shows as a proper role in their life and must be imitated and followed. The fact shows that if the discourse becomes decoded (audience decoding) by 
television connoisseurs, it is very possible that the shows given will deviate from the real one.

The relationship between the owners of the broadcast program and the community is a fractured relationship. The process of producing and receiving messages in the community cannot go hand in hand. The real condition of the relationship is a different understanding of meaning between programmers and society. People receive messages from the television shows as a form of reasonableness and worthiness to consume. More, some even use it as a role model to be imitated or consumed. It is the attitude of request that, then, is read by broadcast providers as a pleasure that must be nurtured and developed to satisfy the communities, though it is not suitable from the real ones.

\subsection{The form of Character Broadcasting on Television Stations}

The regulation in Indonesian television stations is almost entirely based on the Regional Indonesian Broadcasting Commission (KPID). TVRI, although it is a state television, has become the government's long arm in the national broadcasting sector. The prime program in broadcasting so far is music entertainment from various segments which are divided into broadcast time. Teenage music program is aired on afternoons on certain days together with the music program for adults. Problems occur when the music shows played the songs with negative connotations, like the process of news broadcasting must be from two sides and must be balanced. TVRI, as state television, has an active role in informing the public about the programs carried out by the central and regional governments. It is unlike private televisions which tend to deliberately crash existing of the broadcast regulations. Private televisions run independently and they can survive because of the monopoly of the broadcast media. Broadcasting capitalists make the broadcasting substance a business field. They dare to hit the rules to get benefit from broadcasting content which contains local wisdom programs. Similar research related to the importance of broadcasting policy appears in the following explanation: the dominant form of broadcasting in the global era is public service broadcasting. This form of broadcasting serves public interests. Public broadcasting must be free from any commercial and political pressure. Policy makers must be firm and try to provide information that educates the audiences by paying attention to the quality of the programs offered [8].

The idealism of broadcasting to give character base shows is still felt in the world of government television. But, on the other hand, when looking at the broadcasting capitalist world nowadays, it is currently controlled by media conglomeration with diversity ownerships. Some television stations still use a journalistic code of ethics such as Semarang TV which is guided by the policies of KPID. Semarang TV also has its own ethics or regulations that cannot be broken, but that regulation is not related to the substance of broadcasting, such as dressing up and upholding local wisdom and courtesy of the Javanese people.

Semarang TV in giving information is more about local wisdom and also the up-to-date coverage of events around Semarang. In addition to news and events in the local scope, the talk show program is packaged in typical local culture as the use of the language, Javanese language manners and batik dress that make it different from other television stations. The form of awareness of the broadcasting producers is like to celebrate national days. In celebrating the national days, Semarang TV staffs wear national dress. It is done to show the local wisdom and character building to the audiences.

Both TVRI and Semarang TV have received reprimand in the news and in advertising. Private televisions such as Semarang TV in funding must stand by themselves which is sometimes a kind of idealist aside and thinks that this media will be sustainable. And, that is the reason why KPID gives reprimand. On the other side, TVRI, the KPID gives reprimand on the content of medical treatment programs or herbal medicines that should be a regulation of BPOM and also the certificate. It cannot be said that the medicine works in an arbitrary manner without any clinical trials.

Responding to the news as in the local election (Pilkada), TVRI in a political issue must be completely neutral even though it is in the shade of a government station. If one is aired today, the other one also has to be aired, and vice versa, it must be balanced. Semarang TV in political advertisement tries to keep abiding the guidelines set by KPID, but still, there is a possibility of little friction. TVRI and Semarang TV try to improve the image and always keep broadcast of the high quality programs to the communities, one of them through media promotion. As a television station which has not developed nationally yet, Semarang TV plays the advertisement as an important role. Through advertisements, television media can have quite a lot of benefits. But, the idealism of broadcasting on TVRI and Semarang TV is not fully disbursed to be a capitalist commodity that purely pursues profit.

The partiality of broadcasting on the state television does not look at the leadership period. It happens because whoever is in charge is the same that TVRI is still a state television. TVRI is a neutral television station like Semarang TV. If Semarang TV is owned by the individual, TVRI is under a public broadcasting institution. So, indirectly, TVRI is sheltered by the president. As for its organization, it is under the minister of KOMINFO and the budget is subsidized by DPR of Commission I.

Each television station has a different airtime, including TVRI and Semarang TV stations. If Semarang TV only broadcasts from 6:00 to 16:00, then TVRI broadcasts for 24 hours. The interrupted airtime is filled with a local and national content. Regarding news shows on television stations, TVRI is a television station that is selective in choosing and broadcasting 
news, news such as ceremonial is very much avoided by TVRI. They prefer to publish news that has high integrity value, news that is often aired by TVRI in the form of crime, hard news, terrorism and so on, unlike Semarang TV, which only broadcasts news around Semarang and Demak. The news that is aired is only the most updated local broadcast. However, if there is a news vacuum, the attitude taken by TVRI is to fill news shows with humadity life, drought, to the other side of an event.

Advertising is something that must be aired on a television station. It is done because advertising is the biggest contributor to the television station. Therefore, advertisements on television stations usually have no restrictions. Both TVRI and Semarang TV have no restrictions on the advertisement except political advertisement because political advertising is made based on the rule of KPU so that all political advertisements will appear with the same portion for all television stations. Whereas the most serious violation received from KPIs is only a small reprimand. Semarang TV has the most received attention from KPI in the program of Bincang Sehat and TVRI is in the advertisement or event regarding treatment, especially those which are not certified by the BPOM.

\section{Conclusion}

Verbal Abuse forms on television shows include: Reality in broadcasting shows that FTV content, talk shows, and advertisements have the most verbal abuse (VA) frequencies. VA is dominated by abuse, swear, invective and non-VA. Broadcast composition in media is $60 \%$ about educational content with local wisdom character, $20 \%$ of national/international public content and $20 \%$ of advertisement.

It is necessary for all broadcast media to control the health sector, especially in interactive talk shows which is related to the involvement of herbs, prescribing medicines to patients who ask through interactive dialog without any medicine reference policy from the Ministry of Health and BPOM. Strict sanctions are needed from KPID to television stations which make minor violations or serious violations.

\section{References}

1. O. Florescu, Positive and Negative Influences of the Mass Media upon Education, Procedia Social and Behavioral Sciences 149, 349-353 (2014)

2. D. Jamet, M. Jobert, Aspect of Linguistict Impoliteness, British: Cambridge Publisher (2013)

3. D. Kellner, Budaya Media: Cultural Studies, Identitas, dan Politik: Antara Modern dan Postmodern, Yogyakarta: Jalasutra (2010)

4. G. Burton, Media dan Budaya Populer. Yogyakarta: Jalasutra. (2017)

5. B.F. Jeanne, Violence exposure in real-life, video games, television, movies, and the internet: is there desensitization?, Journal of Adolescence 27(1), 23-29 (2003)

6. S. Halim, Postkomodifikasi Media: Analisis Media Televisi dengan Teori Kritis dan Cultural Studies, Yogyakarta: Jalasutra (2013)

7. S. Maria, The impact of globalisation on politeness and impoliteness, Journal of Pragmatics 55, 86-102 (2013)

8. T. Michael, Public Broadcasting (2015) 